\title{
The Crisis of Medicine and the Benefits of Complex Pain Therapy Procedures Such As Cupping: More Research Needed
}

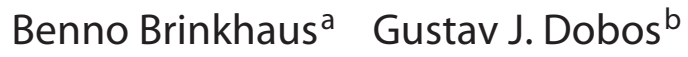 \\ a Institut für Sozialmedizin, Epidemiologie und Gesundheitsökonomie, Projektbereich Komplementäre und \\ Integrative Medizin, Charité - Universitätsmedizin Berlin, Berlin, Germany; ${ }^{\mathrm{b}}$ Department of Internal and Integrative \\ Medicine, Kliniken Essen-Mitte, Faculty of Medicine, University of Duisburg-Essen, Essen, Germany
}

The title of the groundbreaking work by Bernhard Aschner (1883-1960) "Die Krise der Medizin" (The Crisis of Medicine), first published in 1928 and later called "Lehrbuch zur Konstitutionstherapie" (Textbook on Constitutional Therapy), sounds more up-to-date today than ever before. Take, for example, the opioid crisis in the USA, which shows the limits of conventional medicine in a profit-oriented consumer society. The facts about this medical tragedy, where the rapidly increasing consumption of opioid-containing drugs in the USA since the beginning of the 1990s can be observed, are shocking: from 1999 through 2015, more than 183,000 deaths from prescription opioids or substitute drugs are reported, and currently two million Americans are addicted to opioids. The majority of patients were suffering from chronic pain conditions such as chronic back pain or headache and most likely could have been treated effectively by complementary and integrative methods overcoming the pain instead of going down the steady road of addiction. To date, approximately 40,000 to 50,000 pain patients of the two million addicted pain patients die per year [1, 2]. On March 29, 2017, President Donald J. Trump signed an Executive Order establishing the President's Commission on Combating Drug Addiction and the Opioid Crisis [3], and in October 2017 he declared the Opioid Crisis a national emergency of the
American health system. According to chapter 5.3, the Commission has the task besides others to "Identify and describe potential pharmacological and non-pharmacological treatment options, including opioid and non-opioid pharmacological treatments for acute and chronic pain management, along with patient communication and education regarding the risks and benefits associated with each of these available treatment options" [4].

Researchers say that the crisis was actually triggered by the content of a one-paragraph letter to the New England Journal of Medicine published in 1980, barely a hundred words long, which unwittingly became a major contributor to today's opioid crisis. In this letter, Dr. Hershel Jick, a decent scientist, at that time head of the Boston Collaborative Drug Surveillance Program at Boston University Medical Center and senior author, described his analysis of hospitalized patients who had received at least one painkiller. The content of the letter, which fatally underestimated the addiction rate for opioid intake, postulating that "despite widespread use of narcotic drugs in hospital, the development of addiction is rare in medical patients with no history of addiction" was at first hardly recognized. After OxyContin (Oxycodon) was introduced to the American market in 1995, this changed dramatically. Up to date, the letter has been quoted for more than 600 times over the past decades [5]. This statement contained

\section{KARGER}

(C) 2019 S. Karger AG, Basel 
a systematic misinformation of generations of medical students and physicians worldwide about the potential development of addiction after the treatment with narcotics in pain patients, by misusing the Jick letter. The responsible pharmaceutical company, Purdue Pharma, has estimated sales of 35 billion Dollar with OxyContin the responsible drug. Due to the revenue of this single drug, the owners of the company became one of the richest US families. In 2007, Purdue Pharma was pleaded guilty to federal criminal charges (a 635 million Dollar fine) because of misleading regulators, doctors, and patients about the risk of addiction.

In Germany, even though there is stricter control over the release of opioids by the German law, within 5 years (2010 to 2015) the per capita consumption of opioids in Germany increased dramatically by $50 \%$ to a nearly equal level to the American numbers [6], and German experts predict that we are going to face a similar situation of an opioid epidemic in Germany as in the US [7]. In the meantime, research has shown that opioids are only in rare exceptional cases therapy options for chronic pain illnesses. For example, long-term effects of opioids in chronic low back pain (LBP) are unclear, the dependence of patients on opioids for back pain is up to $24 \%$, according to the authors of a systematic review [8]. The authors of a Cochrane up-date came to the same conclusion: while there is evidence of short-acting efficacy of opioids in chronic LBP, the efficacy and safety of long-term therapy has not been demonstrated [9]. The opioid crisis gives reason to think about the role of science [10], new development of drugs, the medical system as a whole, but also in a positive outlook, about the use of non-pharmacologic interventions for chronic pain diseases [11], because non-steroidal anti-inflammatory drugs could also have severe and sometimes fatal side effects [12].

Complex therapy methods of traditional medicine are once again becoming increasingly interesting for conventional medicine: in well-known international journals, acupuncture is being focused on as a therapy option for chronic lumbar spine pain [13-15], and the clinical guidelines of the American College of Physicians explicitly mention several methods of complementary medicine, including acupuncture, mindfulness-based stress reduction, tai chi, yoga, and progressive muscle relaxation [16]. The Guideline even placed acupuncture on the first line of treatment for acute, subacute, and chronic LBP.

Unfortunately, despite promising study results as a treatment for a number of pain conditions, cupping as a complex therapy method did not make it into the guidelines. Coming back to above-mentioned physician and retro-visionary Bernhard Aschner, we find that he dealt with cupping in his textbook on constitutional therapy in detail and that he rightly points out that cupping is a ubiquitous form of therapy that occurs in almost all medical traditions. He refers to the medicine of antiquity (Hippocrates and Galen) in particular, but also to its use in the Middle Ages and at the beginning of modern times. Unfortunately, he forgot the reference to the medical history of the Middle East ancient medicine, which also mentions cupping positively, also in the holy script, the Koran. Aschner, moreover, also quotes Hufeland, temporarily dean of the Charité - Universitätsmedizin Berlin, who complains in his "System der praktischen Heilkunde" (System of Practical Medical Science) (Jena and Leipzig, 1800) that cupping is "an effective, now too much neglected, skin cleansing agent." The crisis of cupping and the abolition of rejection procedures ("Ausleitende Verfahren") get worse with the rapid development of the modern conventional medicine in the middle of the 19th century.

Even today, cupping is still a neglected therapy method, which is being smiled at. In recent years, however, scientific research on the effectiveness of cupping in the treatment of pain has increased, particularly in Germany, especially in Essen and Berlin. It could be shown that cupping has good efficacy in chronic cervical spine, lumbar spine, arthritis, and fibromyalgia pain [17-22], as well as in migraine and tension headache [23]. In the two shamcontrolled studies conducted so far $[19,22]$, there was, however, no evidence of specific efficacy in limitations in the methodology (insufficient statistical power). In recent years, several systematic reviews have also been published, which indicate the efficacy of cupping [24-26], but there is no methodologically well-conducted critical review of all pain disorders. All in all, we need larger multicenter studies on the efficacy of cupping and proof of its good tolerability. Research on a possible mechanism of action must also be intensified, because the research results yielded so far; e.g., the changes in the local tissue metabolism, do not explain the therapeutic effect in toto [27].

As a summary, we postulate that in the face of the opioid crisis in the US. complex traditional therapies should play a more important role in modern medicine. The above-mentioned chapter 5.3 of the President's Commission on Combating Drug Addiction and the Opioid Crisis might be a suitable door-opener for the integration of complex pain treatments. Besides that, we must now intensify our research efforts to bring these therapies back into the world of medicine with rational justification, also for the benefit of our patients. 


\section{References}

1 Center for Disease Control and Prevention. Understanding the Epidemic. Available from: https://www.cdc.gov/drugoverdose/epidemic/index.html.

2 CDC/NCHS CW, Atlanta, GA: US Department of Health and Human Services, CDC. National Vital Statistics System, Mortality. Available from: https://wonder.cdc.gov.

3 The White House - Office of National Drug Control Policy: President's Commission. Available from: https://www.whitehouse. gov/ondcp/presidents-commission/.

4 The New York Times. Available from: https:// www.nytimes.com/2017/10/26/us/politics/ trump-opioid-crisis.html

5 Porter J, Jick H. Addiction rare in patients treated with narcotics. N Engl J Med. 1980 Jan;302(2): 123 .

6 Epidemiologischen Suchtsurveys (ESA) für 2018 [Preprint]. Fast zwei Millionen von Schmerz- und Schlafmitteln abhängig. Available from: https://www.aachener-nachrichten.de/ratgeber/gesundheit/fast-zwei-millionen-von-schmerz-und-schlafmitteln-abhaengig_aid-37909497.

7 WELT - Kaiser T. In Deutschland droht eine Opioid-Epidemie wie in den USA. https:// amp.welt.de/wirtschaft/article174541537/ Schmerzmittel-In-Deutschland-droht-eineOpioid-Epidemie-wie-in-den-USA.html.

8 Martell BA, O’Connor PG, Kerns RD, Becker WC, Morales KH, Kosten TR, et al. Systematic review: opioid treatment for chronic back pain: prevalence, efficacy, and association with addiction. Ann Intern Med. 2007 Jan; 146(2):116-27.

9 Chaparro LE, Furlan AD, Deshpande A, Mailis-Gagnon A, Atlas S, Turk DC. Opioids compared with placebo or other treatments for chronic low back pain: an update of the Cochrane Review. Spine. 2014 Apr;39(7): 556-63.
10 Volkow ND, Collins FS. The Role of Science in Addressing the Opioid Crisis. N Engl J Med. 2017 Jul;377(4):391-4.

11 Glare PA, Nicholas MK, Blyth FM. The Role of Science in the Opioid Crisis. N Engl J Med. 2017 Nov;377(18):1797-8.

12 Tramèr MR, Moore RA, Reynolds DJ, McQuay HJ. Quantitative estimation of rare adverse events which follow a biological progression: a new model applied to chronic NSAID use. Pain. 2000 Mar;85(1-2):169-82.

13 Berman BM, Langevin HM, Witt CM, Dubner R. Acupuncture for chronic low back pain. N Engl J Med. 2010 Jul;363(5):454-61.

14 MacPherson H, Vertosick EA, Foster NE, Lewith G, Linde K, Sherman KJ, et al. The persistence of the effects of acupuncture after a course of treatment: a meta-analysis of patients with chronic pain. Pain. 2017 May; 158(5):784-93.

15 Vickers AJ, VertosickEA, Lewith G, MacPherson H, Foster NE, Sherman KJ, et al.; Acupuncture Trialists' Collaboration. Acupuncture for Chronic Pain: Update of an Individual Patient Data Meta-Analysis. J Pain. 2018 May;19(5):455-74.

16 Qaseem A, Wilt TJ, McLean RM, Forciea MA; Clinical Guidelines Committee of the American College of Physicians. Noninvasive Treatments for Acute, Subacute, and Chronic Low Back Pain: A Clinical Practice Guideline From the American College of Physicians. Ann Intern Med. 2017 Apr;166(7):514-30.

17 Lauche R, Cramer H, Choi KE, Rampp T, Saha FJ, Dobos GJ, et al. The influence of a series of five dry cupping treatments on pain and mechanical thresholds in patients with chronic non-specific neck pain-a randomised controlled pilot study. BMC Complement Altern Med. 2011 Aug;11(1):63.

18 Lauche R, Materdey S, Cramer H, Haller H, Stange R, Dobos G, et al. Effectiveness of home-based cupping massage compared to progressive muscle relaxation in patients with chronic neck pain - a randomized controlled trial. PLoS One. 2013 Jun;8(6):e65378.
19 Lauche R, Spitzer J, Schwahn B, Ostermann T, Bernardy K, Cramer H, et al. Efficacy of cupping therapy in patients with the fibromyalgia syndrome-a randomised placebo controlled trial. Sci Rep. 2016 Nov;6(1):37316.

20 Saha FJ, Schumann S, Cramer H, Hohmann C, Choi KE, Rolke R, et al. The Effects of Cupping Massage in Patients with Chronic Neck Pain - A Randomised Controlled Trial. Complement Med Res. 2017;24(1):26-32.

21 Teut M, Kaiser S, Ortiz M, Roll S, Binting S, Willich SN, et al. Pulsatile dry cupping in patients with osteoarthritis of the knee - a randomized controlled exploratory trial. BMC Complement Altern Med. 2012 Oct;12(1): 184.

22 Teut M, Ullmann A, Ortiz M, Rotter G, Binting S, Cree M, et al. Pulsatile dry cupping in chronic low back pain - a randomized threearmed controlled clinical trial. BMC Complement Altern Med. 2018 Apr;18(1):115.

23 Ahmadi A, Schwebel DC, Rezaei M. The efficacy of wet-cupping in the treatment of tension and migraine headache. Am J Chin Med. 2008;36(1):37-44.

24 Kim S, Lee SH, Kim MR, Kim EJ, Hwang DS, Lee J, et al. Is cupping therapy effective in patients with neck pain? A systematic review and meta-analysis. BMJ Open. 2018 Nov; 8(11):e021070.

25 Li JQ, Guo W, Sun ZG, Huang QS, Lee EY, Wang $\mathrm{Y}$, et al. Cupping therapy for treating knee osteoarthritis: the evidence from systematic review and meta-analysis. Complement Ther Clin Pract. 2017 Aug;28:152-60.

26 Wang YL, An CM, Song S, Lei FL, Wang Y. Cupping Therapy for Knee Osteoarthritis: A Synthesis of Evidence. Complement Med Res. 2018;25(4):249-55.

27 Emerich M, Braeunig M, Clement HW, Lüdtke R, Huber R. Mode of action of cupping-local metabolism and pain thresholds in neck pain patients and healthy subjects. Complement Ther Med. 2014 Feb;22(1):14858 . 